\title{
THE PROHIBITION OF TORTURE AND PERSONS LIVING IN POVERTY: FROM THE MARGINS TO THE CENTRE
}

\author{
Lutz Oette*
}

\begin{abstract}
Torture of persons living in poverty has traditionally been at the margins of human rights interventions that have primarily focused on political and conflict related torture. This article examines the extent to which the evolving practice of human rights bodies and organisations evidences an emerging paradigm shift. It finds that a combination of a growing body of empirical research, novel approaches by human rights organisations and the work of bodies such as the Subcommittee on Prevention of Torture has increasingly brought into focus the heightened vulnerability to torture resulting from economic marginalisation and discrimination. Drawing on evidence of innovative practices, the article develops the framework for a contextual approach to the interpretation and implementation of States' obligations under the prohibition of torture that is alive to the realities of systemic violence and the nexus between poverty and torture.
\end{abstract}

Keywords: human rights, torture, poverty, human rights, discrimination, human rights bodies, human rights organisations.

\section{INTRODUCTION}

If the practice of torture had been confined to persons living in poverty, it would not be absolutely prohibited today. Many would consider such a claim provocative if not blasphemous. Torture is universally prohibited, and all torture is equally reprehensible. This is the universal, abstract, liberal notion underpinning the international prohibition of torture (the prohibition) whose absolute status has been, and continues to be, hard fought for. ${ }^{1}$ These characteristics are part of its appeal and strength. Yet, the prohibition obscures structural differences among its right-holders in terms of being exposed to torture and being able to effectively exercise their rights.

* Reader in International Law, SOAS, University of London, lo8@soas.ac.uk. I am grateful to Morten Koch Andersen, Tobias Kelly, Tom Pegram, Nora Sveaass, Lynn Welchman and the anonymous reviewer for their invaluable comments.

1 M Nowak, M Birk and G Monina, 'Introduction' in M Nowak, M Birk and G Monina (eds), The United Nations Convention against Torture and its Optional Protocol: A Commentary (2nd edn, Oxford University Press 2019) 2-9. 
The special status of the prohibition in international human rights law derives from torture's egregious nature, which is typically associated with extreme, and exceptional, abuse of State power for political ends. ${ }^{2}$ Political torture is frequently at the centre of public accounts, reports, and legal interventions, in other words a matter of international concern. ${ }^{3}$ In contrast, systemic, routine abuse, which disproportionally affects persons living in poverty and other marginalised groups, has been perceived as a national problem of dysfunctional institutions and criminal justice systems. Consequently, its victims, and their experiences, remained largely neglected, or 'underperceived'. ${ }^{4}$

Since the 1970s, when the foundations for the United Nations (UN) Convention against Torture and Other Cruel, Inhuman or Degrading Treatment or Punishment (Convention against Torture) ${ }^{5}$ were laid, international human rights law has undergone significant changes. Multiple challenges to the abstract conception of human rights resulted in the adoption of a series of instruments that reflect a greater focus on the situation of particular groups, with a special emphasis on discrimination, status and vulnerability. This turn is reflected in treaties on the human rights of women, ${ }^{6}$ the child, ${ }^{7}$ persons with disabilities, ${ }^{8}$ migrant workers and members of their families, ${ }^{9}$ and other instruments. ${ }^{10}$ Socio-economic status, while recognised as a ground of discrimination, ${ }^{11}$ has not become the subject of a separate international treaty. Instead, emerging against the background of the perennially contested new international economic order and right to development, ${ }^{12}$ came an international focus on extreme poverty and human rights in the 1990s. Yet,

2 N Rodley with M Pollard, The Treatment of Prisoners under International Law (3rd edn, Oxford University Press 2009) 18-19. 29.

3 R Carver and L Handley, Does Torture Prevention Work? (Liverpool University Press 2016)

4 S Jensen et al., 'Torture and Ill-treatment Under Perceived: Human rights Documentation and the Poor' (2017) 39 HRQ 393. See M Bantjes et al., Finding Our Way: Developing a Community Work Model for Addressing Torture (CSVR and Dignity 2012) 55, on the contrast between antiapartheid victims of torture and contemporary 'unpopular' victims of torture.

5 Adopted 10 December 1984, entered into force 26 June 1987, 1465 UNTS 85.

6 Convention on the Elimination of All Forms of Discrimination against Women (adopted 18 December 1979, entered into force 3 September 1981) 1249 UNTS 13.

7 Convention on the Rights of the Child (adopted 20 November 1989, entered into force 2 September 1990) 1577 UNTS 3.

${ }^{8}$ Convention on the Rights of Persons with Disabilities (adopted 13 December 2006, entered into force 3 May 2008) 2515 UNTS 3.

9 International Convention on the Protection of the Rights of All Migrant Workers and Members of their Families (adopted 18 December 1990, entered into force 1 July 2003) 2220 UNTS 3.

${ }^{10}$ See in particular UN Declaration on the Rights of Indigenous Peoples (adopted 13 September 2007) UNGA Res 61/295.

11 UN Committee on Economic, Social and Cultural Rights, 'General Comment No. 20: NonDiscrimination in Economic, Social and Cultural Rights (art.2, para. 2, ICESCR)' (2 July 2009) UN Doc E/C.12/GC/20, para 33.

${ }^{12}$ UN Human Rights Council, 'Report of the Special Rapporteur on the Right to Development' (2 August 2017) UN Doc A/HRC/36/49. 
three decades later, the UN Special Rapporteur on Extreme Poverty and Human Rights criticised both the development and human rights community for their respective, and joint failure to adequately address violations of civil and political rights, including freedom from torture, of persons living in poverty. ${ }^{13}$

Discrimination serves as both a legal standard of prohibited conduct and as a conceptual lens to describe practices deemed problematic because of the unequal treatment and/or outcomes they engender. Its pivotal role in human rights law stems from the fact that discrimination typically produces, perpetuates or at least contributes to inequality, marginalisation and vulnerability. ${ }^{14}$ Marginalisation refers to processes of social exclusion and denial of power. The lack of equality, recognition, access to resources and services, and participation inherent in marginalisation both causes, and results from, poverty. ${ }^{15}$ Consequently, it enhances vulnerability by heightening the risk of becoming a victim of human rights violations. Poverty is now, as discussed further at III A, widely understood to encompass both absolute and relative poverty, which overlaps with economic inequality. This article adopts a multidimensional and intersectional understanding of poverty attentive to systemic and structural factors, and the enhanced vulnerability to violence that it entails.

Evidence from a variety of sources suggests that a large number of victims of torture are economically disadvantaged (with considerable variations, and often compounded by other factors, such as gender and/or ethnicity). Being poor typically means to be more vulnerable to abuse of power, including arbitrary arrest, detention and torture. These experiences frequently form an integral part of everyday violent relationships with authorities and others that persons living in poverty must navigate. Yes, these realities have not been adequately acknowledged, or addressed in the international human rights law context, with few notable exceptions. ${ }^{16}$ Over the last decade, there has been a growing debate on, and awareness of the detrimental impact of pretrial detention on members of disadvantaged communities, ${ }^{17}$ and of the link between corruption and torture. ${ }^{18}$ In 2018, the UN Special Rapporteur on Torture identified discrimination,

${ }^{13}$ UN Human Rights Council, 'Report of the Special Rapporteur on Extreme Poverty and Human Rights' (4 October 2017) UN Doc A/72/502, para 4.

${ }^{14}$ See in this context the Office of the High Commissioner for Human Rights' (OHCHR) thematic priority over the period 2018-2021 of enhancing equality and countering discrimination, <https://www.ohchr.org/EN/AboutUs/ManagementPlan/Pages/equality.aspx>.

15 See further FW Gatzweiler and H Baumüller, 'Marginality-A Framework for Analyzing Causal Complexities of Poverty' in J von Braun and FW Gatzweiler (eds), Marginality: Addressing the Nexus of Poverty, Exclusion and Ecology (Springer 2014) 27.

16 UN Doc A/72/502 (n 13) paras 9-12.

17 UN Commission on Human Rights, 'Report of the Working Group on Arbitrary Detention' (12 December 2005) UN Doc E/CN.4/2006/7, paras 65-67.

18 UN Human Rights Council, 'Report of the Special Rapporteur on Torture' (16 January 2019) UN Doc A/HRC/40/59; 'Seventh Annual Report of the Subcommittee on Prevention of Torture' (20 March 2014) UN Doc CAT/C/52/2, paras 72-100. 
including socioeconomic marginalisation, as one of the primary challenges regarding the universal implementation of the prohibition. ${ }^{19}$ These developments can be attributed to the influence of pioneering empirical research, increasing focus by non-governmental organisations (NGOs) on the subject, and advocacy on dysfunctional criminal justice systems and marginalisation. ${ }^{20}$ They evidence a growing recognition of the need to complement a standard-based monitoring approach with a closer engagement with socio-political realities. Nonetheless, there has been no in-depth legal analysis in the academic literature, or concerted responses to address the specific challenges raised by practices of torture targeting, or disproportionately affecting persons living in poverty, and their implications for the application of the prohibition.

The lack of an analysis that is informed by a contextual understanding of torture raises important conceptual, legal and strategic questions. It suggests that legal scholars and practitioners working on torture have insufficiently engaged with the wider literature on the link between poverty and (State) violence. ${ }^{21}$ There is limited evidence of interrogating underlying structures and material factors such as the 'logic of particular socio-economic arrangements' highlighted by critical legal scholars, ${ }^{22}$ the causes and impact of hierarchies and exclusions, ${ }^{23}$ or the lived experience of marginalised subjects. ${ }^{24}$

Drawing on both this body of literature and publications on torture, this article revisits the evolution of the prohibition, probing the extent to which it has been responsive to discrimination and vulnerability of economically marginalised persons. It identifies assumptions and biases evident in legal responses to torture and other ill-treatment, before examining the prevalence of torture of persons living in poverty. This analysis provides the basis on which to develop the framework for a contextual approach to the interpretation and implementation of States' obligations and to torture

19 UN Human Rights Council, 'Interim Report of the Special Rapporteur on Torture' (20 July 2018) UN Doc A/73/207, para 65.

${ }_{20}$ TE McCarthy (ed), Attacking the Root Causes of Torture: Poverty, Inequality and ViolenceAn Interdisciplinary Study (OMCT 2006); S Jensen and MK Andersen (eds), Corruption and Torture: Violent Exchange and the Policing of the Urban Poor (1st edn, Aalborg Universitetsforlag 2017); D Celermajer, The Prevention of Torture: An Ecological Approach (Cambridge University Press 2018).

${ }^{21}$ See GA Haugen and V Boutros, The Locust Effect: Why the End of Poverty Requires the End of Violence (Oxford University Press 2014) 82-95; B Rylko-Bauer and P Farmer, 'Structural Violence, Poverty, and Social Suffering' in D Brady and LM Burton (eds), The Oxford Handbook of the Social Science of Poverty (Oxford University Press 2016) 47.

${ }^{22}$ S Marks, 'Human Rights and Root Causes' (2011) 74 MLR 57, 75. Also, U Baxi, The Future of Human Rights (3rd edn, Oxford University Press 2008) 54, 172.

${ }_{23}$ M Campbell, Women, Poverty, Equality: The Role of CEDAW (Hart 2018) 10-26.

24 WP Simmons, Human Rights Law and the Marginalized Other (Cambridge University Press 2011). 
prevention more broadly that is alive to the conditions and lived experiences of those who are often most at risk of torture.

Following this Introduction, Part II situates responses to torture of persons living in poverty in the broader development of international human rights law, namely an increasing emphasis on discrimination and vulnerability of members of certain groups. Revisiting the trajectory of the prohibition shows that the focus on political torture influenced the development of the legal framework and approaches, and delayed a greater recognition of, and adequate responses to the challenges raised by the situation facing particular-marginalised-groups.

Part III explores the notion of poverty in international human rights law, particularly whether it is conceptually sufficiently clear to serve as a basis for tailored, contextual responses to torture. It then analyses the extent to which the definition of torture provides openings to take into consideration the experiences of those living in poverty. At a factual level, it examines whether available evidence shows that persons are more at risk of (certain forms of) torture on account of being poor, and, if so, in which contexts, and whether they face particular challenges in respect of the exercise of their rights.

Part IV develops the parameters of a contextual approach to the interpretation and implementation of the prohibition. It sets out heightened obligations of States before examining which preventive measures are best suited to enhance protection, and what steps can advance accountability and reparation for torture that economically marginalised persons have been subjected to. Further, it explores how non-discrimination and human rights-based approaches to combat poverty might usefully complement torture-specific responses. The contextual approach developed has profound implications and poses challenges for those who work on the prohibition, particularly on how best to respond to, and engage with realities on the ground to bring about change. In examining these challenges, the article argues that a concerted effort is needed to respond to the prevalence of torture on the margins of international concern, and to make those at the receiving end exposed to precarious, and often violent, lives the centrepiece of any strategies to overcome this intolerable state of affairs.

\section{FROM THE UNIVERSAL SUBJECT TO VULNERABLE PERSONS}

\section{A. The Prohibition of Torture and Vulnerable Groups}

The prohibition shares the general trajectory of international human rights law in its recognition of, and heightened focus on discrimination and vulnerability, albeit in a rather belated and more limited fashion. The developments after 1945 point towards a conceptual bias in the dichotomy between political or conflictrelated torture viewed as a matter of international concern, and routine, 
institutionalised torture. ${ }^{25}$ The Convention against Torture's travaux préparatoires evince limited awareness of, and focus on systemic, routine torture. The Convention is silent on the identity of right-holders and victims who are referred to in generic terms. The infliction of severe physical or mental pain or suffering 'for any reason based on discrimination of any kind', as one of the elements of torture, invites a focus on a prohibited ground of discrimination, such as 'social origin' or 'other status' recognised in Article 26 of the International Covenant on Civil and Political Rights. ${ }^{26}$ Yet, the element attracted little discussion during the travaux, ${ }^{27}$ and has played a marginal role in the Committee against Torture's (CAT) initial practice although it was later mentioned in its General Comment No $2 .{ }^{28}$

The last three decades have witnessed an increasing focus on the nexus between discrimination and torture. This focus has emerged in the wake of significant shifts in international human rights law that heralded a closer emphasis on identity and situated experiences. Critiques of universal, liberal and male-oriented human rights conceptions, demands for targeted protection regimes, and sustained advocacy campaigns to recognise the rights of particular groups have resulted in a number of instruments that complement the generic International Bill of Human Rights. ${ }^{29}$ Yet, these treaties either have no explicit reference to torture or include its prohibition among other provisions, commonly stipulating that persons falling within the treaty's scope have the right to be free from torture. ${ }^{30}$

It took considerable time before the issue of torture of members of particular groups became the subject of more detailed attention. This applies in particular to recognising gender-based violence as a form of torture. ${ }^{31}$ More recently, this development has been complemented by an increased focus on torture of lesbian, gay, bisexual, transsexual and intersex persons (LGBTI). ${ }^{32}$

${ }^{25}$ See particularly statement made by Mr Cocks (United Kingdom) on 8 September 1949, European Commission of Human Rights, Preparatory Work on Art. 3 of the European Convention of [sic] Human Rights, DH (56)6 (22 May 1956) 2-5.

${ }_{26}$ Adopted 16 December 1966, entered into force 23 March 1976, 999 UNTS 171.

27 S Dewulf, The Signature of Evil: (Re)Defining Torture in International Law (Intersentia 2011) 308-9.

${ }^{28}$ UN Committee against Torture, 'General Comment No. 2: Implementation of Article 2 by States Parties' (24 January 2008) UN Doc CAT/C/GC/2, para 20.

${ }^{29}$ Baxi (n 22).

${ }_{30}$ See eg Convention on the Rights of Persons with Disabilities, art 15.

${ }^{31}$ UN Human Rights Council, 'Reports of the Special Rapporteur on Torture' (15 January 2008) UN Doc A/HRC/7/3; (5 January 2016) UN Doc A/HRC/31/57; UN Committee on the Elimination of Discrimination against Women, 'General Recommendation No. 35 on Gender-Based Violence against Women, Updating General Recommendation No.19' (26 July 2017) UN Doc CEDAW/C/ $\mathrm{GC} / 35$.

32 Principle 9, 'The Yogyakarta Principles - Principles on the Application of International Human Rights Law in Relation to Sexual Orientation and Gender Identity' (International Commission of Jurists March 2007): OHCHR, 'Discrimination and Violence against Individuals Based on Their Sexual Orientation and Gender Identity' (4 May 2015) UN Doc A/HRC/29/23; Committee against Torture, 'Ninth Annual Report of the Subcommittee on Prevention of Torture' (22 March 2016) UN Doc CAT/C/57/4, paras 48-82. 
Children have been recognised to be at risk of harm in detention because of 'their stage of development and limited capacity to escape or react to abuse emanating from their environment'. ${ }^{33}$ Persons with disabilities are exposed to torture in various settings on account of mental health challenges, lack of capacity and ability to resist certain treatment, ${ }^{34}$ vulnerability due to impairments, ${ }^{35}$ and inadequate accommodation in detention resulting in unacceptable levels of suffering. ${ }^{36}$ Indigenous peoples have been identified as being especially vulnerable to torture in the context of armed conflict, protest movements and development projects. ${ }^{37}$ Racial discrimination as a factor motivating torture, or increasing the risk thereof, has been highlighted in respect of several countries. ${ }^{38}$ Recently, the experience of refugees and other migrants has received considerable attention. Their precarious status, harsh policies, and xenophobia frequently exposes them to the risk of torture or other ill-treatment. ${ }^{39}$

UN anti-torture bodies have accorded greater importance to vulnerability in their recent practice. In 2018, the CAT identified women, children, LGBTI people in detention, minorities and indigenous peoples in prison, lifesentenced prisoners, people who use drugs, and prisoners with physical and mental disabilities as vulnerable groups of detainees. ${ }^{40}$ The Special Rapporteur on Torture has drawn an explicit link between discrimination and an enhanced risk to torture and identified several vulnerable groups. He has defined vulnerability in relational terms

as a degree of disempowerment relative to the prevailing environment and circumstances, entailing diminished independence and capacity for selfsustenance, self-protection or self-preservation and, conversely, an increased exposure to risks of injury, abuse or other harm. ${ }^{41}$

33 UN Doc A/73/207 (n 19) para 68; UN Human Rights Council, 'Report of the Special Rapporteur on Torture' (5 March 2015) UN Doc A/HRC/28/68, para 33.

34 UN Human Rights Council, 'Report of the Special Rapporteur on Torture' (1 February 2013) UN Doc A/HRC/22/53; Subcommittee on Prevention of Torture, 'Approach of the Subcommittee on Prevention of Torture and Other Cruel, Inhuman or Degrading Treatment or Punishment Regarding the Rights of Persons Institutionalized and Treated Medically without Informed Consent' (26 January 2016) UN Doc CAT/OP/27/2.

35 Munir Al Adam v Saudi Arabia, Decision adopted 20 September 2018, UN Doc CRPD/C/20/ $\mathrm{D} / 38 / 2016$.

${ }^{36} X v$ Argentina, Decision adopted 11 April 2014, UN Doc CRPD/C/11/D/8/2012.

37 Inter-American Commission on Human Rights, 'Indigenous Peoples, Afro-Descendent Communities, and Natural Resources: Human Rights Protection in the Context of Extraction, Exploitation and Development Activities' (31 December 2015) OEA/Ser.L/V/II, Doc 47/15; Favela Nova Brasilia v Brazil (Preliminary Objections, Merits, Reparations and Costs) InterAmerican Court of Human Rights Series C No 333 (16 February 2017).

$38 \mathrm{P}$ Thornberry, The International Convention of the Elimination of All Forms of Racial Discrimination: A Commentary (Oxford University Press 2016) 321-6.

39 UN Human Rights Council 'Report of the Special Rapporteur on Torture' (23 November 2018) UN Doc A/HRC/37/50.

${ }^{40}$ Penal Reform International, PRI works with UN Committee against Torture to Address Vulnerable Groups in Detention (7 August 2018) < https://www.penalreform.org/news/pri-workswith-un-committee-against-torture-to/ $>$.

41 UN Doc A/73/207 (n 19) para 64. 
These responses acknowledge the need to tailor measures and responses to the specific situation and experiences of members of vulnerable groups.

The conceptual work undertaken by human rights bodies and the jurisprudence of regional courts on the vulnerability of certain groups to human rights violations ${ }^{42}$ signal a more situation-specific understanding of human rights and States' obligations. It has been criticised, though, on account of its expansionist tendency and broadening even further the positive obligations of States. ${ }^{43}$ Even for those generally sympathetic to the notion, there are obvious risks in designating groups as inherently vulnerable. Such approach may detract from the inherent vulnerability of all human beings. ${ }^{44}$ It might create new hierarchies, be ad hoc, focusing primarily on certain groups whose plight has been prominent in public debates, and result in a lack of conceptual clarity and consistency. ${ }^{45}$ This is particularly the case where different instruments and bodies identify different groups, or do not consistently refer to specific groups, as being vulnerable. It also risks treating members of a group in an undifferentiated fashion, thereby replicating a generic approach on a group basis. ${ }^{46}$ Further, referring to members of a group as vulnerable might be patronising and constitute a form of essentialist labelling that can be unduly stigmatising and victimising. ${ }^{47}$ An approach to vulnerability that is cognisant both of the material, societal, political and institutional factors producing it, and the rights, dignity and agency of persons finding themselves in such situations appears best suited to minimise these risks.

\section{B. The Prohibition of Torture and Persons Living in Poverty}

In 2017, the Special Rapporteur on Extreme Poverty and Human Rights pointedly criticised the limited focus of the human rights and the development community on civil and political rights violations of persons living in extreme poverty. ${ }^{48}$ A review of the record of UN bodies specifically mandated to promote and protect the right to be free from torture largely vindicates Alston's critique. The mandate of the Special Rapporteur on Torture was established in 1985. It took until 2000 for a mandate holder

\footnotetext{
${ }^{42}$ L Peroni and A Timmer, 'Vulnerable Groups: The Promise of an Emerging Concept in European Human Rights Convention Law’ (2013) 11 IJCL 1056.

${ }^{43}$ M Bossuyt, 'Categorical Rights and Vulnerable Groups: Moving Away from the Universal Human Being' (2016) 48 GeoWashIntlLRev 717.

${ }^{44}$ BS Turner, Vulnerability and Human Rights (Pennsylvania State University Press 2006).

45 See further E Virokannas, S Liuski and M Kuronen, 'The Contested Concept of Vulnerability - A Literature Review’ 23 European Journal of Social Work 327.

46 Peroni and Timmer (n 42) 1063, refer to vulnerability as 'relational, particular, and harmbased'. $95 \mathrm{ff}$.

47 R Kapur, Erotic Justice: Law and the New Politics of Postcolonialism (Glass House 2005)
} 
explicitly to highlight the exposure of persons living in poverty to torture, before concluding:

The Special Rapporteur has neither the competence nor the expertise to offer solutions to change these bleak realities. He believes, however, that as long as national societies and, indeed, the international community fail to address the problems of the poor, the marginalized and the vulnerable, they are indirectly and, as far as exposure to the risk of torture is concerned, directly contributing to the vicious circle of brutalization that is a blot on and a threat to our aspirations for a life of dignity and respect for all. ${ }^{49}$

This paragraph usefully draws attention to the dual challenge of addressing poverty, understood as a condition that increases vulnerability to violations, and of providing protection to those exposed to the risk of torture on account of that condition. However, the Special Rapporteur did not assume responsibility for how his mandate could contribute to change the equation between poverty and torture he had identified. Subsequent reports identified poverty as a factor in the context of exposure to, reasons for, and methods of torture that victims were subjected to, without, however, elaborating in greater detail on the implications of such findings. ${ }^{50}$ Significantly, 20 years after the then Special Rapporteur highlighted the failure to act on the link between poverty and torture, no thematic report has been dedicated to the subject.

However, in 2018 a report of the Special Rapporteur explored the link between discrimination and torture, and explicitly referred to socioeconomic marginalisation as 'an important factor exposing persons to abuse by States and non-State actors'. ${ }^{51}$ This was followed by a report on corruption and torture, which highlighted how corruption exposes socio-economically marginalised persons to an enhanced risk of torture. ${ }^{52}$

The CAT has referred to discrimination and socio-economic status in its practice, albeit inconsistently. Its General Comment No 2 emphasised the principle of non-discrimination. ${ }^{53}$ It stated that ' $[\mathrm{t}]$ he protection of certain minority or marginalised individuals or populations especially at risk of torture is part of the obligation to prevent torture or ill-treatment', mentioning, amongst others, social origin and economic or indigenous status as relevant statuses. ${ }^{54}$ The Committee stressed the need for 'data disaggregated by age, gender and other key factors' to enable '[c]ontinual evaluation $\ldots$ of effective measures', 55 without, however, specifically referring to socioeconomic status. It further exhorted States parties to

49 UN Human Rights Council, 'Interim Report of the Special Rapporteur on Torture' (11 August 2000) UN Doc A/55/290, para 37.

50 UN Human Rights Council 'Report of the Special Rapporteur on Torture' (5 February 2010)

UN Doc A/HRC/13/39/Add.5, para 251.

${ }^{52}$ UN Doc A/HRC/40/59 (n 18) para 57.

55 ibid para 23.

53 (n 28) para $20 . \quad 54$ ibid para 21. 
describe 'factors affecting the incidence and prevention of torture or illtreatment, as well as the difficulties experienced in preventing torture or illtreatment against specific relevant sectors of the population, such as minorities, victims of torture, children and women ...?.56 While only illustrative, the listed groups reflect the Committee's priority focus.

In its subsequent practice of reviewing States parties' reports it has not insisted on the provision of disaggregated data concerning socio-economic status. ${ }^{57}$ It has neither, notwithstanding expressing concerns in this regard, developed a consistent practice of adopting tailored recommendations in response to evidence of systemic torture disproportionately affecting the poorer strata of society. A pertinent example are the Committee's limited responses to alternative reports submitted by the NGO World Organisation against Torture (OMCT) and partner organisations which provided in-depth contextual assessments that highlighted issues such as corruption and torture of the urban poor in Kenya, and the lack of land reform and violent policing against impoverished members of rural communities in the Philippines. ${ }^{58}$

The Committee's General Comment No. 3 mentions specific vulnerable groups and grounds of prohibited discrimination, including economic status, and exhorts States parties to adopt special measures to ensure access to redress mechanisms, ${ }^{59}$ without, however, providing detailed guidance specifically tailored to persons living in poverty. ${ }^{60}$

A lack of specific focus on poverty and discrimination is also evident in the Committee's practice of inquiries, which, according to Article 20(1) of the Convention against Torture, require 'reliable information ... that torture is being systematically practised'. The Committee has considered 'that torture is practised systematically when it is apparent that the torture cases reported ... are seen to be habitual, widespread and deliberate in at least a considerable part of the territory of the country in question. ${ }^{61}$ This criterion may be met in cases of routine, systemic torture by law enforcement agencies. ${ }^{62}$ Yet, as evident in the inquiries carried out by the Committee to date, its main focus has been on torture

\footnotetext{
56 ibid.

57 The Committee has requested disaggregated data on sex, age, ethnicity, and nationality; see eg UN Committee against Torture, 'Concluding Observations on the Initial Report of Pakistan' (1 June 2017) UN Doc CAT/C/PAK/CO/1, para 45.

${ }^{58}$ UN Committee against Torture, 'Concluding Observations of the Committee against Torture: Kenya’ (19 January 2009) UN Doc CAT/C/KEN/CO/1, para 12.

${ }^{59}$ UN Committee against Torture, 'General Comment No. 3: Implementation of Article 14 by States Parties' (13 December 2012) UN Doc CAT/C/GC/3, para 29. $\quad 60$ ibid para 32.

${ }^{61}$ UN General Assembly 'Report: Addendum, Summary Account of the Results of the Proceedings Concerning the Inquiry on Turkey’ (15 November 1993) UN Doc A/48/44/Add.1,

${ }^{62}$ However, see Brazil's position, arguing that systematic torture requires a deliberate plan or policy, UN Committee against Torture, 'Report on Brazil produced by the Committee under Article 20 of the Convention and Reply from the Government of Brazil' (3 March 2009) UN Doc CAT/C/ $39 / 2$, para 241 .
} para 39. 
in the context of counterterrorism and conflict. ${ }^{63}$ Some of the inquiries, such as on Mexico, Yugoslavia (Serbia and Montenegro), Brazil, Nepal, and Lebanon, addressed the issue of institutionalised torture, at least to some extent. However, even these inquiries either did not refer to the socio-economic status of victims or, where they showed some awareness, did not systematically link recommendations back to the findings that torture has a distinctive socioeconomic dimension. ${ }^{64}$

In its jurisprudence, the Committee has not explicitly dealt with the nexus of poverty and torture. In their individual opinion in the case of Dzemajl et al. $v$ Yugoslavia, two of its members drew attention to the special vulnerability of the 'Romani ethnic group', and the greater protection that the State must afford. ${ }^{65}$ They also stressed the poverty resulting from their ill-treatment and forced displacement. In Osmani v Serbia, the Committee considered the particular vulnerability of the victim, who was of Roma ethnic origin, on account of historical discrimination and prejudice when determining whether treatment reached the threshold of Article 16 of the Convention. ${ }^{66}$ However, it did not draw out any further legal consequences flowing from such discrimination and vulnerability.

The Subcommittee on Prevention of Torture's (SPT) practice is in marked contrast to that of other UN bodies. It has shown considerable awareness of the role that poverty and discrimination plays, and how it enhances exposure to the risk of torture:

It is also recognized that there is a nexus between poverty, discrimination and pretrial detention. It is known that the poorest and most marginalized individuals or groups in society are most likely to come into contact with the criminal justice system and therefore to be held in pretrial detention. They can be disadvantaged and discriminated against by the criminal justice system in a number of ways, for example if they are unable to afford legal representation, bail and other alternatives to detention. Discriminatory attitudes may also expose them to conditions of detention stricter than those applied to other detainees. ${ }^{67}$

${ }^{63}$ UN Doc A/48/44/Add.1 (n 61); UN Committee against Torture, Egypt (3 May 1996) UN Doc A/51/44(SUPP), paras 180-222; Peru (12 October 2001) UN Doc A/56/44(SUPP), paras 144-193; Sri Lanka (17 October 2002) UN Doc A/57/44(SUPP), paras 117-195; Egypt (23 June 2017) UN Doc A/72/44, paras 58-71.

${ }^{64}$ However, see Brazil, UN Doc CAT/C/39/2 (n 62) para 137, '[a]lmost all the detainees were persons who had previously lived in difficult socio-economic conditions, with a low level of education and belonged to vulnerable social groups'; Lebanon, UN General Assembly (2 October 2014) UN Doc A/69/44, Annex XIII, para 29, evidence of 'a clear pattern of widespread torture and ill-treatment of suspects in custody ... and individuals arrested in the course of civil policing, in particular lower-income individuals arrested for minor crimes'.

65 Dzemajl et al. v Yugoslavia, Decision adopted 21 November 2002, UN Doc CAT/C/29/D/ 161/2000, Individual Opinion by Mr. Fernando Mariño and Mr. Alejandro Gonzáles Poblete, (e).

${ }_{66}$ Osmani v Serbia, Decision adopted 8 May 2009, UN Doc CAT/C/42/D/261/2005.

${ }^{6}$ UN Committee against Torture, 'Eight Annual Report of the Subcommittee on Prevention of Torture' (26 March 2015) UN Doc CAT/C/54/2, para 78. 
The SPT has been particularly assertive when highlighting the pernicious effect of corruption on persons living in poverty, finding, in the first report produced by a UN body dedicated to the subject, that 'there is a strong correlation between the levels of corruption within a State and the levels of torture and ill-treatment found there' ${ }^{68}$

The practice of regional human rights bodies on the link between socioeconomic status and torture differs considerably. The African Commission on Human and Peoples' Rights' Robben Island Guidelines include references to vulnerable groups but not to socio-economic discrimination. ${ }^{69}$ The Commission has included a list of questions on vulnerable persons as part of its State reporting review procedure, albeit not with reference to persons living in poverty. ${ }^{70}$ Recently, it has highlighted discrimination and marginalisation in its General Comment No $4^{71}$ and in its Guidelines on the Conditions of Arrest, Police Custody and Pre-Trial Detention in Africa, ${ }^{72}$ although rarely in its jurisprudence. ${ }^{73}$ In the most pertinent ruling on the nexus between poverty and torture by an African human rights body, the African Committee of Experts on the Rights and Welfare of the Child held Senegal responsible for its failure to protect children aged between 4 and 12 years who had been forced by Qur'anic schools to beg on the streets and had been subjected to miserable living conditions and physical abuse. ${ }^{74}$

The European Court of Human Rights has dealt with a number of Article 3 (prohibition of torture) cases that raised issues of the treatment of persons from disadvantaged backgrounds. In its case law, the Court has increasingly recognised the link between discrimination and torture, with reference to grounds such as race, ${ }^{75}$ gender, ${ }^{76}$ sexual orientation, ${ }^{77}$ political opinion, ${ }^{78}$ religion, ${ }^{79}$ and the different status of detainees. ${ }^{80}$ Its approach has, however,

68 UN Doc CAT/C/52/2 (n 18) para 82.

69 African Commission on Human and Peoples' Rights, 'Guidelines and Measures for the Prohibition and Prevention of Torture, Cruel, Inhuman or Degrading Treatment or Punishment in Africa (The Robben Island Guidelines)' (23 October 2002) arts 36, 45.

${ }^{70}$ Committee for the Prevention of Torture in Africa, 'State Periodic Reporting under Article 62 of the African Charter on Human and Peoples' Rights: Indicative Questions to States Parties in respect of Article 5 of the African Charter' (29 April 2019) paras 16-18.

71 African Commission on Human and Peoples' Rights, 'General Comment No. 4 on the African Charter on Human and Peoples' Rights: The Right to Redress for Victims of Torture and Other Cruel, Inhuman or Degrading Punishment or Treatment (Article 5)' (4 March 2017).

72 African Commission on Human and Peoples' Rights, 'Guidelines on the Conditions of Arrest, Police Custody and Pre-Trial Detention in Africa' (9 March 2015).

73 However, see Gabriel Shumba v Zimbabwe, Comm No 288/2004, Decision, 51st ordinary session of the ACHPR, 18 April-2 May 2012, para 144, referring to discriminatory torture.

74 The Centre for Human Rights (University of Pretoria) and La Rencontre Africaine pour la Defense des Droits de l'Homme (Senegal) v Government of Senegal, Decision No 003/Com/001/ 2012, 15 April 2014.

${ }_{75}$ See eg M. F. v Hungary, Appl No 45855/12, Judgment of 31 October 2017.

76 Bălsan v Romania, Appl No 49645/09, Judgment of 23 May 2017.

77 M.C. and A.C. v Romania, Appl No 12060/12, Judgment of 12 April 2016.

78 Virabyan v Armenia, Appl No 40094/05, Judgment of 2 October 2012.

79 Begheluri and Others v Georgia, Appl No 28490/02, Judgment of 7 October 2014.

${ }^{80}$ Gülay Çetin v Turkey, Appl No 44084/10, Judgment of 5 March 2013. 
also been characterised by a lack of in-depth engagement with relevant socioeconomic factors. Bouyid v Belgium is a landmark case in point. ${ }^{81}$ It concerned a situation of long-standing tensions between the local police and a family with a migration background that resulted in police officers slapping a 17-year-old boy and his older brother. The Grand Chamber held that any person in a custodial situation is vulnerable, with recourse to physical violence diminishing the person's dignity, and emphasised the vulnerability of minors which require law-enforcement officers to 'show greater vigilance and self-control'. ${ }^{82}$ The case illustrates the Court's predilection for the formulaic invocation of principles and factors, here a liberal notion of dignity combined with generic vulnerability, instead of probing to what extent institutional practices and the status of the victim may have contributed to the ill-treatment.

The Inter-American Commission on Human Rights (Inter-American Commission) has undertaken numerous country visits in which it has drawn attention to structural factors, including the nexus between poverty and human rights violations, which it has also addressed in its thematic reports. ${ }^{83}$ The Inter-American Court of Human Rights (Inter-American Court) has developed a jurisprudence marked by its close attention to the link between structural factors, status (often multiple), discrimination and vulnerability, particularly in cases of gender-based violence, ${ }^{84}$ and ill-treatment of children, ${ }^{85}$ indigenous peoples, ${ }^{86}$ persons with mental disabilities,${ }^{87}$ and migrants. ${ }^{88}$ It has repeatedly emphasised poverty and socio-economic circumstances as factors to be taken into consideration, ${ }^{89}$ including in cases of torture, such as in Ximenes Lopes $v$ Brazil where it drew attention to the intersectional dimension of extreme poverty, age, indigenous peoples and mental disabilities. ${ }^{90}$ The Court has also ordered reparation measures designed to tackle the root causes of discriminatory treatment of marginalised

81 Bouyid v Belgium, Appl No 23380/09, GC Judgment of 28 September 2015.

82 ibid para 110.

83 See eg Inter-American Commission on Human Rights, 'Preliminary Observations of IACHR's In Loco Visit to Brazil' (12 November 2018); 'Poverty and Human Rights in the Americas' (7 September 2017) OEA/Ser.L/V/II.164 Doc 147.

${ }^{84}$ Women Victims of Sexual Torture in Atenco $v$ Mexico (Preliminary Objection, Merits, Reparations and Costs) Inter-American Court of Human Rights Series C No 371 (28 November 2018) para 177.

85 'Street Children' (Villagrán Morales et al.) v Guatemala (Merits) Inter-American Court of Human Rights Series C No 63 (19 November 1999).

${ }^{86}$ Fernández Ortega et al. v Mexico (Preliminary Objections, Merits, Reparations and Costs) Inter-American Court of Human Rights Series C No 215 (30 August 2010).

87 Ximenes Lopes v Brazil (Merits, Reparations and Costs) Inter-American Court of Human Rights Series C No 149 (4 July 2006).

${ }^{88}$ Vélez Loor v Panama (Preliminary Objections, Merits, Reparations and Costs) InterAmerican Court of Human Rights Series C No 218 (23 November 2010).

89 In Vereda La Esperanza $v$ Colombia (Preliminary Objections, Merits, Reparations and Costs) Inter-American Court of Human Rights, Series C No 341 (31 August 2017) para 240, the court stated the general principle that persons living in poverty are more severely affected by violations on account of their greater vulnerability.

90 Ximenes Lopes Case (n 87) para 104. 
persons. ${ }^{91}$ The overview shows that UN treaty bodies, special procedures mandate holders and regional human rights systems have increasingly addressed issues of discrimination, marginalisation and vulnerability of members of various groups to torture, albeit not necessarily with a primarily focus on its socio-economic dimension.

\section{Non-Governmental Organisations and Torture of Persons Living in Poverty}

Human rights bodies do not operate in a vacuum. They are closely connected to both NGOs and academia in terms of personnel and working relationships. The 'anti-torture movement' consisting of NGOs and others working on the prohibition may be said to constitute both a transnational network ${ }^{92}$ and an epistemic community. Such a community has been described as 'a network of professionals with recognised expertise and competence in a particular domain and an authoritative claim to policy-relevant knowledge within that domain or issue-area' ${ }^{93}$ whose members use 'shared discursive practices' ${ }^{94}$ Such communities influence governance through their ideas and understanding of social realities, whereby shared understandings are sustained and developed by 'a community of practice'. ${ }^{95}$ Actors working on the prohibition share these characteristics, though there are significant differences in the approaches taken.

The anti-torture movement has been largely characterised by a legal orientation combined with a medical and social focus on rehabilitation. ${ }^{96}$ The legal approach has been aimed at enhanced legislative and institutional protection through engagement with human rights bodies. Organisations have mostly operated within the existing anti-torture paradigm and responded to developments in other fields rather than taking the lead in framing discourses. Their approaches have been characterised by limited consideration of structural factors sustaining the practice of torture and related discourses. The criticism expressed at the nature and modus operandi of the human rights movement writ large therefore applies to a considerable degree to the actors constituting the anti-torture movement. ${ }^{97}$

However, notably, some NGOs have engaged with the nexus between poverty, discrimination and torture. OMCT issued a landmark interdisciplinary study in $2006 .{ }^{98}$ It found that '[S]tate violence, understood

91 González et al. ('Cotton Field') v Mexico (Preliminary Objection, Merits, Reparations and Costs) Inter-American Court of Human Rights Series C No 205 (16 November 2009) para 450.

${ }_{92}$ ME Keck and K Sikkink, Activists Beyond Borders: Advocacy Networks in International Politics (Cornell University Press 1998).

93 PM Haas, 'Introduction: Epistemic Communities and International Policy Coordination' (1992) 46 IntlOrg 1, 3.

94 ibid note 5.

95 J Brunnée and SJ Toope, Legitimacy and Legality in International Law: An Interactional Account (Cambridge University Press 2010) 352.

96 For an overview of prevention approaches, see Celermajer (n 20) 44-65.

97 Marks (n 22); Baxi (n 22). $\quad{ }^{98}$ McCarthy (n 20). 
as political terror, torture and incarceration, is highly correlated with broader composite socio-economic indexes, with income as the single most powerful explanatory socio-economic factor. ${ }^{\prime 99}$ Dignity, a Danish-based human rights organisation, has made a distinctive contribution to torture prevention by focusing on policing and the urban poor, ${ }^{100}$ and the link between corruption, poverty and torture, including detailed country studies on the Philippines, South Africa, Kenya and Bangladesh. ${ }^{101}$ The Asian Human Rights Commission (AHRC), an NGO based in Hong Kong, has persistently highlighted the socio-economic dimension of torture, and documented people's exposure to corruption and police abuse. ${ }^{102}$ It has linked the persistence of these practices to the weakness of criminal justice systems and advocated for the strengthening of the rule of law and relevant institutions as key prerequisites for the effective prohibition of torture. ${ }^{103}$

A review of recent reports published by Amnesty International and Human Rights Watch as two major NGOs working on torture indicates an increasing emphasis on policing and its impact on particularly vulnerable groups. ${ }^{104}$ The emerging approach is highly contextual, often with a focus on specific groups. ${ }^{105}$ Organisations with a medical focus, namely the International Rehabilitation Council for Torture Victims (IRCT), have also highlighted the link between poverty and torture, calling on States 'to include the eradication of torture and the right to rehabilitation in their poverty reduction policies and strategies, including all development policies and programmes'. ${ }^{106}$

This brief review shows that at least some human rights organisations have recognised the significance of poverty in their work on torture. Alston's critique that the civil and political rights of persons living in poverty 'are completely ignored, explicitly excluded from the analysis or mentioned only in passing' ${ }^{107}$ therefore needs to be more nuanced when considering the record of anti-torture organisations. Nonetheless, a number of structural factors, particularly NGOs being frequently staffed by middle class personnel, based in capitals, and focusing on high-profile cases, can be antithetical to anti-

\section{9 ibid 13.}

100 See eg J-A Prud'Homme et al., Legal Study on Policing and Human Rights Standards: Internationally and in Three Countries of the Global South (South Africa, Philippines and Liberia) (Dignity 2017).

101 Jensen and Andersen (n 20).

102 B Fernando (ed), Narratives of Justice in Sri Lanka Told through Stories of Torture Victims (Asian Legal Resource Centre 2013).

${ }^{103}$ MK Andersen and B Fernando, The Phantom Limb: Failing Judicial Systems, Torture and Human Rights Work in Sri Lanka - A Study of Police Torture in Sri Lanka (RCT and AHRC 2009).

104 See eg Amnesty International, Paper Promises, Daily Impunity: Mexico's Torture Epidemic Continues (2015); 'Welcome to Hell Fire': Torture and Other Ill-Treatment in Nigeria (2014); Above the Law: Police Torture in the Philippines (2014); Human Rights Watch, 'Good Cops are Afraid': The Toll of Unchecked Police Violence in Rio de Janeiro (2016).

105 See eg Human Rights Watch, 'They Treat Us Like Animals': Mistreatment of Drug Users and 'Undesirables' in Cambodia's Drug Detention Centres (2013); 'Take that Filth Away': Police Abuses against Street Vendors in Angola (2013).

106 The London Declaration on Poverty and Torture (IRCT 11 November 2011).

107 UN Doc A/72/502 (n 13) para 1. 
torture work that is informed by, and responsive to the realities experienced by people living in poverty. ${ }^{108}$

\section{POVERTY AND TORTURE: CONCEPTS, EVIDENCE AND PRACTICE}

\section{A. The Notion of Poverty}

The World Bank has defined poverty pithily as 'pronounced deprivation in wellbeing'. ${ }^{109}$ Poverty has traditionally been largely defined with reference to income and purchasing power. ${ }^{110}$ As used in the Sustainable Development Goal 1: 'End poverty in all its forms everywhere', it refers to an income of less than $\$ 1.90$ a day, revised upward from $\$ 1.25$ in 2015.11 Absolute poverty is measured based on the income needed to meet basic needs. ${ }^{112}$ The absolute poverty line has been criticised as being too low, covering at best only basic necessities in the poorest countries. ${ }^{113}$

The notion of relative poverty has the advantage of reflecting the standards of living in a particular society, thereby broadening the geographic scope beyond the world's poorest regions, and casting a spotlight on inequality within societies. ${ }^{114}$ Relative poverty is commonly defined with reference to the percentage (50-60 per cent) by which income falls below the median income. ${ }^{115}$ Such percentage provides a useful indicator although it can describe widely divergent realities. The Inter-American Development Bank has developed a more nuanced, graduated system of indicators for the Americas, divided into the extreme poor (income of under $\$ 2.50$ a day); moderate poor $(\$ 2.50-4)$; vulnerable class $(\$ 4-10)$; middle class $(\$ 10-50)$; high-income class (over \$50). ${ }^{116}$ The strength of the conventional incomebased approach is its measurability, even though there are methodological difficulties in estimating the income and purchasing power needed to meet basic needs. ${ }^{117}$ It can serve as a useful indicator of poverty when documenting, monitoring and researching the socio-economic background of (alleged) torture victims.

\footnotetext{
108 Jensen et al. (n 4); CA Fuentes, Contesting the Iron Fist: Advocacy Networks and Police Violence in Democratic Argentina and Chile (Routledge 2005) 52-67.

109 World Bank, World Development Report 2000/2001: Attacking Poverty (Oxford University Press 2000) 15.

110 See IACHR, 'Poverty' (n 83) paras 35ff.

111 M Ravallion and S Chen, Welfare-Consistent Global Poverty Measures (World Bank Group, Policy Research Working Paper 8170 2017). $\quad{ }^{112}$ IACHR, 'Poverty' (n 83) paras 38-40.

113 SG Reddy and TW Pogge, 'How Not to Count the Poor' in S Anand, P Segal and JE Stiglitz (eds), Debates on the Measurement of Global Poverty (Oxford University Press 2010) 42. See for a scathing critique of the World Bank's approach, and on Covid-19 as a 'pandemic of poverty', UN Human Rights Council 'Report of the Special Rapporteur on Extreme Poverty and Human Rights' (2 July 2020) UN Doc A/HRC/44/40.

114 TM Smeeding, Poverty Measurement in Brady and Burton (n 21) 21, 28.

115 ibid., $29 . \quad 116$ IACHR, 'Poverty' (n 83) 24.

117 M Ravallion, 'A Reply to Reddy and Pogge' in Anand, Segal and Stiglitz (n 113) 86.
} 
This utility notwithstanding, a notion of poverty based on income and consumption that focuses exclusively on the most basic needs for survival is inadequate in a human rights context. Sen's work in particular has fundamentally transformed the prevailing understanding of poverty as deprivation of capabilities, which are understood as 'the substantive freedoms [a person] enjoys to lead the kind of life he or she has reason to value'. ${ }^{118}$ Sen's approach, which has moved poverty beyond the purely economic sphere, has been influential in shaping the discourse on, and institutional understandings of development and poverty. ${ }^{119}$ The resulting multidimensional understanding is shared by persons living in poverty who have emphasised material poverty, dependency, feelings of helplessness, inability to participate in culturally defining activities, humiliation suffered at the hands of various actors and a sense of acute vulnerability stemming from destitution. ${ }^{120}$

The broader debate on poverty has been reflected in the work of human rights bodies. The UN Guiding Principles on Extreme Poverty and Human Rights (the Guiding Principles) ${ }^{121}$ constitute the main human rights reference document, serving 'as a guide to how to respect, protect and fulfil the rights of persons living in extreme poverty in all areas of public policy'. ${ }^{122}$ They refer to the definition of poverty set out by the Committee on Economic, Social and Cultural Rights as

a human condition characterized by sustained or chronic deprivation of the resources, capabilities, choices, security and power necessary for the enjoyment of an adequate standard of living and other civil, cultural, economic, political and social rights. ${ }^{123}$

The definition acknowledges Sen's influence, incorporates structural factors and is noteworthy for explicitly linking the condition of poverty to the enjoyment of a range of human rights, including civil and political rights. The Guiding Principles define extreme poverty as

'the combination of income poverty, human development poverty and social exclusion' where a prolonged lack of basic security affects several aspects of people's lives simultaneously, severely compromising their chances of exercising or regaining their rights in the foreseeable future. ${ }^{124}$

118 A Sen, Development as Freedom (Oxford University Press 1999) 87.

119 UNDP, Human Development Report 2000: Human Rights and Human Development (2000) 73.

120 D Narayan et al., Voices of the Poor: Can Anyone Hear Us? (Oxford University Press for the World Bank 2000).

121 UN Human Rights Council Res. 21/11, UN Doc A/HRC/RES/21/11 (27 September 2012).

122 UN Human Rights Council, 'Final Draft of the Guiding Principles on Extreme Poverty and Human Rights' (18 July 2012) UN Doc A/HRC/21/39, para 11.

${ }^{123}$ UN Committee on Economic, Social and Cultural Rights, 'Substantive Issues Arising in the Implementation of the International Covenant on Economic, Social and Cultural Rights: Poverty and the International Covenant on Economic, Social and Cultural Rights' (10 May 2001) UN Doc E/C.12/2001/10, para $8 . \quad 124$ Guiding Principles (n 122) para 2 (citations omitted). 
This definition integrates the conventional income poverty and human development approach and highlights social exclusion as a factor that undermines the exercise of rights. While social exclusion has now been recognised as an integral part of the notion, '[p]overty is related to, but distinct from, inequality and vulnerability'. ${ }^{125}$ Exclusion is closely linked to discrimination, and often has an intersectional dimension, as recognised in the Guiding Principles:

Although persons living in extreme poverty cannot simply be reduced to a list of vulnerable groups, discrimination and exclusion are among the major causes and consequences of poverty. Persons living in poverty often experience disadvantage and discrimination based on race, gender, age, ethnicity, religion, language or other status. ${ }^{126}$

These definitions view the lack of basic security as an integral part and consequence of poverty, an acknowledgment that is particularly relevant in the context of exposure to torture. As demonstrated below at III D., poverty and related inequalities create power imbalances ${ }^{127}$ and structure relationships ${ }^{128}$ in ways that significantly enhance vulnerability to a spectrum of violence which frequently amounts to torture or other ill-treatment. These features call for a conceptualisation that views exposure to a heightened risk of ill-treatment as intrinsic to poverty, whereby the specific forms that such violations take are determined by the particular context.

Subjective understandings and perceptions of poverty are important if a human rights-based approach to poverty is to be taken seriously. While the 'voices of the poor' ${ }^{129}$ are not the sole criterion for defining poverty, they play a critical role in understanding the conditions of poverty and their nexus to torture, and in developing adequate policy responses. In that regard, Jensen et al. have rightly stressed the intersectional and multidimensional nature of poverty, counselling against thinking 'about the poor as a unified group'. ${ }^{130}$

\section{B. Poverty and the Interpretation of Torture and Other Ill-Treatment}

Severity and purpose are the two elements in the definition of torture in Article 1 of the Convention against Torture that lend themselves to an interpretation attentive to poverty as a relevant characteristic. Severity of pain or suffering is to be determined taking into consideration objective and subjective factors. ${ }^{131}$ The European Court of Human Rights has in this regard referred

\footnotetext{
125 J Haughton and SR Khandker, World Bank Handbook on Poverty and Inequality (2009) 3.

126 Guiding Principles (n 122), para 8.

127 See on the notion of powerlessness (n 136-7).

128 On poverty as a structural problem having an adverse impact on human rights, see IACHR, Poverty (n 83) para 101. $\quad{ }_{129}$ Narayan et al. (n 120). $\quad{ }_{130}$ Jensen et al. (n 4) 395.

131 On the subjective dimension of torture, see P Pérez-Sales, Psychological Torture: Definition, Evaluation and Measurement (Routledge 2017).
} 
to personal characteristics such as 'sex, age and state of health of the victim'. ${ }^{132}$ The Inter-American Court has endorsed this approach and developed it further, emphasising that 'the personal features of an alleged victim of torture ... should be taken into consideration when determining whether his or her personal integrity has been violated' 133 as they 'may change the insight of his or her individual reality and, therefore, increase the suffering and the sense of humiliation ...' 134 The CAT has also considered vulnerability as a relevant factor in its jurisprudence. ${ }^{135}$

Poverty, or socio-economic status as a protected characteristic, is a factor that enhances vulnerability because of the precariousness and lesser protection that it typically entails. In situations where the treatment is ostensibly inflicted to target or exploit the socially conditioned diminished ability to defend oneself against abuse of power, it is also likely to increase the level of humiliation and suffering. The degree of powerlessness of the victim is an important factor in this context. Powerlessness is here not understood generically as the inability to defend oneself in a custodial setting, ${ }^{136}$ but as 'symbolic exclusion from the human community'. ${ }^{137}$ Torture of an already marginalised person aggravates such exclusion, particularly where it takes place in a continuum of violence committed against that person with impunity.

The socio-economic characteristics of a person may also be relevant for the infliction of severe pain or suffering 'for any reason based on discrimination of any kind' or, in short, discriminatory torture. ${ }^{138}$ The discriminatory element in Article 1 of the Convention relates to the motive for the treatment, and has a potentially broad field of application. ${ }^{139}$ It will be of particular relevance where the circumstances of a case indicate that persons have been targeted on account of their socio-economic status. ${ }^{140}$ Insults, harassment or threats that invoke this status, stigmatising or stereotyping persons, and targeting and abusing individuals because of their socially constructed lower status and consequent diminished ability to protect and defend themselves, are key indicators of such discriminatory treatment. Systemic patterns of differential treatment, including higher arrest, detention, and confession rates, which

132 Selmouni v France, Appl No 25803/94, GC Judgment of 28 July 1999, para 100.

133 Ximenes Lopes Case (n 87) para 127.

135 Dzemajl Case (n 65) para 9.2, and individual opinion.

136 UN Commission on Human Rights, 'Report of the Special Rapporteur on Torture' (23 December 2005) UN Doc E/CN.4/2006/6, paras 39-40.

137 E Webster, Dignity, Degrading Treatment and Torture in Human Rights Law: The Ends of Article 3 of the European Convention on Human Rights (Routledge 2018) 130.

138 Shumba Case (n 73) para 144. See further, S Dewulf, 'The Prohibition of Discriminatory Torture in International Law' in A Alen et al. (eds), Liberae Cogitationes: Liber Amicorum Marc Bossuyt (Intersentia 2013) 241, 247-8.

139 Dewulf, ibid, 247-9, emphasises the risk that an expansive interpretation of this element trivialises torture.

${ }^{140}$ For the definition of direct discrimination in international human rights law, see UN Committee on the Rights of Persons with Disabilities, 'General Comment No. 6 (2018) on Equality and Non-Discrimination' (26 April 2018) UN Doc CRPD/C/GC/6’, para 18(a). 
cannot be objectively justified, are indicators of indirect discrimination. ${ }^{141}$ Subjecting persons living in poverty to worse detention conditions, coercive extortion practices and particularly harsh forms of ill-treatment might also constitute prima facie evidence of discriminatory treatment. This is particularly the case where other, wealthier persons are treated more favourably in a similar situation. In addition to, or in lieu of, the discriminatory element, the purpose requirement will be met where it can be shown that persons living in poverty are forced to confess to a crime, where they are intimidated or coerced, including the extortion of money or services, and where they are punished for their conduct, because it is considered socially deviant, criminal or otherwise unacceptable.

Vulnerability stemming from, and discrimination related to poverty may serve as important factors in the determination of whether certain conduct amounts to cruel, inhuman or degrading treatment. The notion of degrading treatment is particularly salient, with its emphasis on feelings of 'fear, anguish or inferiority capable of breaking an individual's moral and physical resistance' and humiliation demonstrating 'a lack of respect for, or diminishing, his or her human dignity'. ${ }^{142}$ The concept of dignity, though characterised by its indeterminacy in international human rights law, ${ }^{143}$ provides considerable potential to contextualise the limits of acceptable treatment of persons living in poverty.

Waldron's observation that treatment must be considered inhuman when it runs counter to 'our common humanity' 144 is particularly valuable, as it alludes to the equal worth of every human person irrespective of one's status. Webster conceives of dignity as 'an elemental status, which is diminished by, and demands freedom from, experiences that undermine a minimal kind of regard or capacity'. ${ }^{145}$ She further links humiliation 'to a lack of a basic ability to maintain standards that are socially deemed to befit human beings'. ${ }^{146}$ This interpretation provides suitable criteria as to what constitutes acceptable treatment. A possible objection to its application to persons living in poverty would be that their elemental status is already diminished, which may adversely impact their self-respect. Feelings of fear, anguish and inferiority and experiences of humiliation are often an integral part of living in poverty. However, such an argument would be fallacious. The condition of poverty may not as such trigger the responsibility of the State for 'treatment' falling within the scope of the prohibition. ${ }^{147}$ However, such an assessment

141 ibid para 18(b) on indirect discrimination.

142 Pretty v United Kingdom, Appl No 2346/02, Judgment of 29 April 2002, para 52.

143 C McCrudden, 'Human Dignity and Judicial Interpretation of Human Rights' (2008) 19 EJIL 655.

$144 \mathrm{~J}$ Waldron, Torture, Terror and Trade-Offs: Philosophy for the White House (Oxford University Press 2010) 304. $\quad 145$ Webster (n 137) 58. 146 ibid 75 (original emphasis).

147 See further L Oette, 'Austerity and the Limits of Policy-Induced Suffering: What Role for the Prohibition of Torture and Other Ill-Treatment?' (2015) 15 HRLR 669. 
neither lowers the threshold for treatment that any person is entitled to nor gives State agents licence to treat persons in a way that reinforces the status and feelings associated with poverty. The prohibition of degrading treatment instead requires States not to treaty persons living in poverty as having lesser worth than others, particularly by not reinforcing, aggravating or exploiting the specific vulnerabilities that poverty entails.

\section{Prevalence of Torture of Persons Living in Poverty}

Several sources emphasise that persons living in poverty are at particular risk of, and are frequently subjected to torture. ${ }^{148}$ However, it is notoriously difficult to establish the extent of torture practices and widely acknowledged that torture is under-reported. ${ }^{149}$ In the absence of reliable statistics or sufficiently specific scales, the prevalence and forms of torture of persons living in poverty must be deduced from a variety of sources. These sources include victim testimonies, statements of witnesses and perpetrators of such practices, and further evidence collected by those working in the field. ${ }^{150}$

Notwithstanding this wealth of information, there are several limitations and challenges when considering the utility of available sources. Human rights reports have addressed torture of persons living in poverty, albeit largely incidentally. UN bodies have not developed a coherent methodology of documenting or reporting relevant forms of torture. The Inter-American Commission has addressed the nexus between poverty and human rights in a major thematic report but only made passing reference to torture. ${ }^{151}$ The utility of torture-related jurisprudence is diminished by the practice common to several bodies of not focusing on the socio-economic profile of complainants. Even where the facts suggest that there is a correlation between the torture and the socio-economic background of a person, a focus on the nature and purpose of the ill-treatment, rather than its victims, frequently means that reported cases lack the requisite detail to draw out useful conclusions.

The most valuable sources on torture of persons living in poverty are research reports, several of which resulted from NGO-led projects. OMCT's 2006 report found a strong correlation between the Hathaway torture scale and socioeconomic variables, based on series of detailed country studies. ${ }^{152}$ Subsequent OMCT shadow reports provided evidence on the link between

148 P Van Reenen, 'Routine Police Torture: Towards a Personalistic Analysis and Strategy' (2002) 4 HRR 52, 56; UN Doc A/HRC/13/39/Add.5 (n 50) paras 231, 251; UN Doc A/73/207 (n 19) para 65; Carver and Handley (n 3) 36.

149 REDRESS, Justice for Torture Worldwide: Law, Practice and Agendas for Change (2013) 14.

${ }^{150}$ R Wahl, Just Violence: Torture and Human Rights in the Eyes of the Police (Stanford University Press 2017); Fuentes (n 108) 46-8; Jensen and Andersen (n 20); Haugen and Boutros (n 21); Narayan et al. (n 120).

151 IACHR, 'Poverty' (n 83) para 415.

152 McCarthy (n 20). 
poverty and torture in Brazil, Kenya, the Philippines and Uzbekistan. ${ }^{153}$ Over the last decade, the AHRC has published several reports on the torture of persons living in poverty, particularly in Sri Lanka. ${ }^{154}$ Amnesty International, Human Rights Watch and other human rights organisations have documented the torture of specific groups whose members typically live in poverty, such as children living on the street, drug users, and street traders. ${ }^{155}$ This includes the gendered dimension of torture, such as of sex workers in Lebanon ${ }^{156}$ and alcohol brewers and tea sellers in Sudan. ${ }^{157}$

Carver and Handley's research on the effectiveness of torture prevention methods, commissioned by the NGO Association for the Prevention of Torture, included several country studies which found that persons living in poverty have been disproportionately targeted by law enforcement agencies. ${ }^{158}$ Further empirical research has produced evidence of similar practices in countries such as Kenya, Nepal and Bangladesh, ${ }^{159}$ South Africa, ${ }^{160}$ and, in the context of marginalisation and political opposition, in Papua, Indonesia. ${ }^{161}$

However, NGOs are seen to have under-reported poverty-related torture due to strategic priorities, such as a focus on political and conflict-related torture, and several structural factors. Jensen et al. argue that urban location, class background and modus operandi of NGOs are important factors. Based on empirical research in Kenya, Bangladesh and Nepal, they found that NGOs treat torture as extraordinary events which privilege a focus on political torture, are physically and mentally distant from low-income neighbourhoods, and focus on places of detention rather than the street. They are predisposed towards prosecution and reparation rather than protection, which is often a priority for persons living in poverty, who may also not fit into NGO assumptions about what it means to be a 'good victim'. ${ }^{162}$ These

153 OMCT, Report on Implementing OMCT's Project, Preventing Torture and Other Forms of Violence by Acting on Their Economic, Social and Cultural Root Causes: 2007-2010<www.omct. org/en/resources/reports/report-on-implementing-omcts-project-preventing-torture-and-otherforms-of-violence-by-acting-on-their-economic-social-and-cultural-root-causes-2007-to-2010>.

154 B Fernando and SR Weerawickrame, A Baseline Study on Torture in Sri Lanka (AHRC 2012); Fernando (n 102). $\quad{ }^{155}$ Amnesty International and Human Rights Watch (n 104).

${ }^{156}$ Human Rights Watch, 'It's Part of the Job': Ill-Treatment and Torture of Vulnerable Groups in Lebanese Police Stations (2013).

157 REDRESS and SIHA, Criminalisation of Women in Sudan: A Need for Fundamental Reform (2017). 158 Carver and Handley (n 3) 390-1 (South Africa), 519-20 (India).

159 Jensen et al. (n 4).

160 M Langa et al., 'Torture and Corruption: Violent Exchanges in Marginalized South African Communities' in Jensen and Andersen (n 20) 69.

161 B Hernawan, 'Torture as a Mode of Governance: Reflections on the Phenomenon of Torture in Papua, Indonesia' in M Slama and J Munro (eds), From 'Stone-Age' to 'Real-Time': Exploring Papuan Temporalities, Mobilities and Religiosities (ANUP 2015) 195.

162 Jensen et al. (n 4) 396. T Kelly, S Jensen and MK Andersen, 'Fragility, States and Torture' in MD Evans and J Modvig (eds), Research Handbook on Torture: Legal and Medical Perspectives on Prohibition and Prevention (Edward Elgar 2020) 63, 70ff focus on situations of relative fragility characterised by institutional weaknesses, resource constraints, and limited State legitimacy and accountability. They highlight several issues that differ from conventional assumptions about 
perceptions and resulting approaches may be fostered and reinforced by international actors, including donors and partner NGOs, who often play an influential role in setting priorities. These practices contribute to perpetuating, even if inadvertently, existing socio-economic marginalisation.

Another factor in the limited documentation and reporting of such torture is persons living in poverty themselves. Their lack of standing, influence and agency is apt to translate into vicious circles that reinforce the powerlessness that torture inscribes. There are also practical considerations. In addition to such factors as a lack of connections with influential persons, including access to NGOs or the media, persons living in poverty will often not be in a position where complaining or going public is a viable option. Their social standing may be such that their plight, even where they allege torture, engenders little sympathy. ${ }^{163}$ The fact that they are typically powerless in essentially violent power relationships with officials or those close to them equates to a systemic lack of protection, which is often compounded by dysfunctional justice systems. Limiting visibility is in these circumstances a self-preservation strategy, which explains the reluctance to pursue cases further and have them documented. ${ }^{164}$

\section{An Anatomy of Torture of Persons Living in Poverty}

The scale and nature of torture of persons living in poverty varies considerably between countries, and within countries. ${ }^{165}$ It also varies in terms of disproportionately affecting certain groups within this broader category. Developing an understanding of relevant practices therefore requires a contextual approach based on an analysis of the specific situation. Nonetheless, there are some common patterns that allow generic findings to be drawn out concerning the circumstances, profile of victims, modalities of torture, and their consequences and responses. The following account focuses on policing and criminal justice as routine setting for forms of violence that involve public authorities. ${ }^{166}$

A distinctive feature of relevant practices is the prevalence of various forms of ill-treatment outside the detention context. Many persons living in poverty are highly visible. Living on the street is often criminalised which provides the authorities with considerable scope to harass or ill-treat persons, including

torture, namely the nature and role of public authorities, the prevalence of extra-custodial torture and the nexus between corruption and torture.

163 D Rejali, 'Modern Torture as Civic Marker: Solving a Global Anxiety with a New Political Technology’ (2003) 2 JHR 153, 158.

164 MK Andersen, 'Why Corruption Matters in Human Rights' (2018) 10 JHRP 179, 182-3.

165 A country's level of income is viewed as a strong indicator for the extent of torture, which indicates that the practice is more widespread in low-income countries; McCarthy (n 20).

166 Torture by private actors is only considered to the extent that there is an element of acquiescence by public officials or other persons acting in an official capacity which brings it within the scope of art 1 of the Convention against Torture. 
children, ${ }^{167}$ in the form of largely arbitrary policing. ${ }^{168}$ Certain occupations, such as street traders, sex workers, or others working in the informal economy face criminalisation in several countries, or are subject to police discretion on public order grounds. ${ }^{169}$

Policing ostensibly aimed at repressing conduct deemed worthy of criminal sanction or suppression has a disproportionate impact on persons engaging in these occupations. ${ }^{170}$ Police and other agencies in several countries are known to extort money or demand sexual acts, which amount to a form of ill-treatment, from persons living and working on the street, in exchange for favours, including not pursuing possible charges or releasing an arrested person. Illtreatment is used to enforce demands made or punish resistance. ${ }^{171}$ While economically marginalised persons command limited resources, they provide a lucrative source of steady income or services, such as sex, with limited attendant risk of adverse repercussions for those engaging in extortionate practices. Another feature of corrupt practices is police torture to enforce the interests of powerful private actors, including politicians, such as in the context of slum clearances, development projects, violent removal of homeless persons and children from the street, or the settling of disputes. ${ }^{172}$ For persons living in poverty, public authorities, particularly the police, often represent an ongoing threat, forcing them to navigate what are at best ambivalent and typically violent relationships with law enforcement agencies. ${ }^{173}$

They are also at a higher risk of arrest, detention and incarceration due to discriminatory law enforcement practices. A number of studies demonstrate a clear link between social status, especially level of income, and intersecting factors, such as race, on the one hand, and the scale of arrest, detention and imprisonment of members of relevant groups on the other. ${ }^{174}$ In many systems, investigators primarily rely on confessions, which increases the likelihood that persons from a marginalised background are forced to confess

\footnotetext{
${ }^{167}$ UN Human Rights Council, 'Report of the United Nations High Commissioner for Human Rights on the Protection and Promotion of the Rights of Children Working and/or Living on the Street' (11 January 2012) UN Doc A/HRC/19/35, paras 25-8; UN Committee on the Rights of the Child, 'General Comment No. 21 (2017) on Children in Street Situations' (21 June 2017) UN Doc $\mathrm{CRC} / \mathrm{C} / \mathrm{GC} / 21$, para 60 .

${ }_{168}$ UN Human Rights Council, 'Report of the Special Rapporteur on Extreme Poverty and Human Rights' (4 August 2011) UN Doc A/66/265, paras 29-43. $\quad{ }^{169}$ ibid para 39.

${ }^{170}$ HRW, 'Take That Filth Away' (n 105).

171 UN Doc A/HRC/40/59 (n 18) paras 28, 31-3.

172 ibid para 34. See also country studies in Jensen and Andersen (n 20); case studies in Haugen and Boutros (n 21).

173 Narayan et al. (n 120) 249-55.

${ }^{174}$ UN Doc A/66/265 (n 168) paras 65-70; OHCHR, 'Non-discrimination and the protection of persons with increased vulnerability in the administration of justice, in particular in situations of deprivation of liberty and with regard to the causes and effects of overincarceration and overcrowding' (21 August 2017) UN Doc A/HRC/36/28, paras 14-29; UN Doc CAT/C/54/2 (n 67) para 78; Open Society Foundations, Ludwig Boltzmann Institute of Human Rights and University of Bristol Human Rights Implementation Centre, Pretrial Detention and Torture: Why Pretrial Detainees Face the Greatest Risk (2011) 28.
} 
to a crime. ${ }^{175}$ Law enforcement agents operating on the basis of such profiling and framing do so for good reason; there is often institutional, political and public support, and there is limited risk of adverse publicity or legal action taken because the targets lack connections, resources and/or trust in the system. An example is the arrest, detention and ill-treatment of poor drug users. ${ }^{176}$ The police may also use torture as a form of instant punishment in dysfunctional criminal justice systems. Notably, Wahl found that Indian police officers distinguished between the torture of innocent persons, which was deemed unacceptable, and the punishment of 'criminals', which they considered morally justified. ${ }^{177}$

Torture of persons living in poverty frequently has specific geographical and gendered dimensions. In urban settings, young males living in poor neighbourhoods are often liable to being framed for certain crimes, as they are susceptible to regular raids and profiling. ${ }^{178}$ They are also at risk of torture where their conduct, particularly defiance, is perceived to challenge police authority. ${ }^{179}$ Where children are arrested, their mothers may be confronted with a choice of paying for their release and/or being subjected to sexual violence, or facing the alternative of the continued detention if not illtreatment of their sons. ${ }^{180}$ In detention, persons who lack the requisite means are often exposed to overcrowding and the worst detention conditions, and may not be able to secure protection against abuse by other inmates, including sexual violence. ${ }^{181}$ In rural areas, it is particularly members of marginalised communities who are at risk of torture. ${ }^{182}$ Members of social movements or protesters against policies or projects detrimental to persons living in poverty have also been subjected to torture. ${ }^{183}$

Persons living in poverty typically lack the means to afford access to a lawyer or bail, and do not pursue legal avenues due to concerns over their safety and

175 UN Human Rights Council, 'Interim Report of the Special Rapporteur on Torture' (5 August 2016) UN Doc A/71/298, paras 8-15; 'Report of the Special Rapporteur on Torture, Addendum: Mission to Mexico' (29 December 2014) UN Doc A/HRC/28/68/Add.3, para 29; Amnesty International, Above the Law, and 'Welcome to Hell Fire' (n 104).

${ }^{176}$ UN Human Rights Council, 'Report of the Special Rapporteur on Torture, Addendum: Mission to Indonesia' (10 March 2008) UN Doc A/HRC/7/3/Add.7, paras 20-22; HRW, 'They Treat Us Like Animals' (n 105); Rejali (n 163) 157.

177 Wahl (n 150). See also Carver and Handley (n 3) 88 (Argentina).

178 See Bulacio $v$ Argentina (Merits, Reparations and Costs) Inter-American Court of Human Rights Series C No 100 (18 September 2003) 24-25, expert opinion of Sofia Tiscornia; HRW, 'Good Cops' (n 104).

179 M Langa, 'Stories of Torture Survivors Who Sought Redress in Post-Apartheid South Africa' (CSVR 2015) <https://csvr.org.za/pdf/Stories\%20of\%20Torture\%20Survivors\%20.pdf> 26.

${ }^{180}$ L Gudmundsen, L Vestergaard and S Jensen, 'Gendered Violence in Informal Settlements in Kenya' in Jensen and Andersen (n 20) 104.

${ }^{181}$ UN Human Rights Council, 'Human Rights Implications of Overincarceration and Overcrowding' (10 August 2015) UN Doc A/HRC/30/19, 30-31.

182 See eg Human Rights Watch, “"Trigger Happy”: Excessive Use of Force by Indian Troops at the Bangladesh Border' (2010).

183 Subcommittee on Prevention of Torture, "Visit to Peru: 10-20 September 2013: Observations and Recommendations to the State Party' (9 August 2017) UN Doc CAT/OP/PER/1, paras 23-26. 
lack of trust in justice systems. ${ }^{184}$ Human rights defenders who have defended torture victims in these circumstances have themselves been the subject of smear campaigns and harassment. ${ }^{185}$ In addition, the filtering of cases and the modus operandi of NGOs and the media has resulted in the lack of legal support and publicity, which are critical factors in pursuing investigations. ${ }^{186}$ The resulting impunity of perpetrators is an important factor in perpetuating powerlessness and insecurity and maintaining institutionalised abuse.

\section{A CONTEXTUAL APPROACH TO TORTURE OF PERSONS LIVING IN POVERTY}

\section{A. Conceptual Foundations of a Contextual Approach}

A contextual approach of preventing and responding to torture of economically marginalised persons builds on a rich scholarship and practice of interpreting and implementing human rights. This includes calls to vernacularise human rights, ${ }^{187}$ to recognise the specific characteristics of right-holders, including exposure to particular forms of discrimination and abuse, ${ }^{188}$ and to be attentive to their lived experiences, including their rights and agency, ${ }^{189}$ and the role of systemic factors, material structures and power relations. ${ }^{190}$ Drawing on these strands, a contextual approach is characterised by being situational, relational and structural. It is informed by how the specific characteristics of a person are situated in and impacted by relationships that result in enhanced exposure to abuse of power, taking into consideration wider structural factors. Its aim of advancing both protection and the effective realisation of rights requires that the rights of persons living in poverty and their experiences in specific contexts are fully taken into consideration when interpreting and implementing the prohibition.

The Special Rapporteur on Torture and the SPT have referred to structural factors such as power asymmetry, inequality and socioeconomic marginalisation in their examination of what causes an enhanced risk of torture. ${ }^{191}$ However, the reference to structural causes often remains formulaic in the absence of any in-depth engagement with the wider literature

\footnotetext{
184 UN Human Rights Council, 'Report of the Special Rapporteur on Torture' (9 February 2010) UN Doc A/HRC/13/39, para 54. Further Haugen and Boutros (n 21).

185 UN Human Rights Council, 'Report of the Special Rapporteur on the Situation of Human Rights Defenders on His Mission to Mexico' (12 February 2018) UN Doc A/HRC/37/51/Add.2, paras 20, 44, 68 .

186 MK Andersen, 'Filtering Information: Human Rights Documentation in Bangladesh' (2019) 11 JHRP 73; Fuentes (n 108) 52-65.

187 S Engle Merry, 'Transnational Human Rights and Local Activism: Mapping the Middle' (2006) 108 AmAnthr 38.

188 See eg Campbell (n 23).

189 Simmons (n 24); G Heathcote, Feminist Dialogues on International Law: Successes, Tensions, Futures (Oxford University Press 2019).

190 See Celermajer (n 20); Baxi (n 22); Marks (n 22).

191 UN Doc A/73/207 (n 19) para 63; Subcommittee on Prevention of Torture, 'The Approach of the Subcommittee on Prevention of Torture to the Concept of Prevention of Torture' (30 December 2010) UN Doc CAT/OP/12/6, para 5.
} 
in relevant disciplinary fields. Engagement with notions such as State crime, ${ }^{192}$ social control of crime, ${ }^{193}$ failing criminal justice systems ${ }^{194}$ and structural violence $^{195}$ is an indispensable prerequisite for identifying causes, patterns and factors that can be used to inform States' obligations and legal responses, as well as other policy interventions.

\section{B. Heightened Obligation of States}

The CAT has interpreted the Convention against Torture as imposing an obligation on States parties to protect marginalised persons at risk of torture. ${ }^{196}$ The Special Rapporteur on Torture referred to this as a 'heightened obligation to protect vulnerable persons from abuse', and called on States to interpret the 'torture protection framework' with particular reference to human rights norms prohibiting discrimination and protecting vulnerable persons. ${ }^{197}$ This interpretation builds on the principle that States need to take effective measures against and in response to torture. However, neither the Committee nor the Special Rapporteur have specified the nature of such an obligation in respect of persons living in poverty.

A heightened obligation to protect applies in respect of all persons living in extreme poverty who must be considered vulnerable in all circumstances on account of the lack of means, capabilities and, typically, inferior social status. It equally applies to members of certain groups, eg children in street situations, and occupations, such as street traders and sex workers. Considering the nexus between discrimination and torture, the same rationale applies where members of a group are known to have been disadvantaged and/or subjected to stigma and stereotyping that enhances vulnerability. The heightened obligation needs to be interpreted contextually, taking into consideration other relevant factors, such as age, gender, or race, thereby making it intersectional where applicable. The obligation requires States to take specific measures designed to protect members of a group, as recognised in the Guiding Principles. ${ }^{198}$ States must also consider the impact of detrimental policies, engrained patterns, and structural factors, particularly discriminatory practices that enhance vulnerability, on the implementation of specific obligations arising under the prohibition. The heightened obligation therefore has a potentially broad,

\footnotetext{
192 P Green and T Ward, State Crime: Governments, Violence and Corruption (Pluto Press 2004).

${ }^{193}$ International Council on Human Rights Policy, Crime, Public Order and Human Rights (2003).

194 V Munasinghe and D Celermajer, 'Acute and Everyday Violence in Sri Lanka' (2017) 47 Journal of Contemporary Asia 615.

195 J Galtung, 'Violence, Peace, and Peace Research' (1969) 6 Journal of Peace Research 167, 171-2, 178; S Lee, 'Poverty and Violence' (1996) 22 Social Theory and Practice 67.

196 General Comment No 2 (n 28), para 21; Dzemajl Case (n 65), Individual opinion, referring to 'greater protection' on account of especial vulnerability of the group.

197 UN Doc A/73/207 (n 19) para $64 . \quad{ }_{198}$ Guiding Principles (n 122).
} 
cross-cutting dimension that significantly enhances States' obligations in respect of persons living in poverty.

\section{Preventive measures}

Article 2(1) of the Convention against Torture stipulates a far-reaching obligation for States parties to take effective measures to prevent torture. The CAT's General Comment No 2 implies an obligation to consider heightened exposure to torture on account of discrimination. While 'the Committee's understanding of ... effective measures [is] in a process of continual evolution' ${ }^{199}$ and hence open to contextual interpretation, it has not provided further guidance tailored to the situation of persons living in poverty. The following analysis focuses primarily on what measures States ought to take in their criminal justice systems as a priority area of concern.

Criminalisation of living on the streets or occupations and activities frequently associated with poverty enhances the risk for those concerned of being exposed to various forms of corruption and ill-treatment. The Guiding Principles call on States to '[a]ssess and address any disproportionate effect of criminal sanctions and incarceration proceedings on persons living in poverty' and decriminalise what it refers to 'life-sustaining activities in public places' ${ }^{200}$ The Principles on the Decriminalisation of Petty Offences in Africa counsel that enforcement of laws criminalising petty offences 'perpetuates the stigmatisation of poverty by mandating a criminal-justice response to what are socio-economic and sustainable development issues', ${ }^{201}$ and draw the link to resulting overcrowding in detention. ${ }^{202}$ Both of these instruments provide important guidance on the interpretation of States' obligations to take effective preventive measures. Consequently, States must carefully consider to what extent continued criminalisation enhances the risk of torture, and what measures ought to be taken to minimise any such risk.

Criminalisation is closely linked to the widespread recourse to pretrial detention. Several human rights bodies have addressed the link between excessive pretrial detention and a heightened risk of torture, as well as ill-treatment on account of poor detention conditions, particularly overcrowding. ${ }^{203}$ Its prevalence has been attributed to systemic failings of criminal justice systems, lack of safeguards and a culture of impunity. ${ }^{204}$ The SPT has emphasised the connection between poverty, discrimination and

\footnotetext{
199 General Comment No 2 (n 28) para 4.

${ }^{200}$ Guiding Principles (n 122) para 66.

201 African Commission on Human and Peoples' Rights, 'Principles on the Decriminalisation of Petty Offences in Africa' (25 October 2018) Part 3, para 7. 202 ibid Part 4, paras 9-10.

203 See eg UN Secretary-General, 'Human Rights in the Administration of Justice: Analysis of the International Legal and Institutional Framework for the Protection of All Persons Deprived of Their Liberty' (5 August 2013) UN Doc A/68/261, paras 40-42.

204 Open Society Foundations, Ludwig Boltzmann Institute and University of Bristol (n 174).
} 
prolonged pretrial detention. ${ }^{205}$ It has urged States to consider alternatives to pretrial detention, an obligation that already flows from the prohibition of arbitrary deprivation of liberty. ${ }^{206}$ Decriminalisation and reduction of pretrial detention therefore constitute crucial systemic measures to prevent torture in these circumstances.

In order to be effective, the generic framework of preventive measures must be tailored to the situation of persons living in poverty. Carver and Handley found that safeguards in the initial phase following arrest, monitoring mechanisms, and prosecutions have been the most effective measures in preventing torture. ${ }^{207}$ These measures, while undoubtedly important, may be of limited utility for persons living in poverty who may lack the trust in the system, information and financial means to exercise their rights. Human rights bodies have repeatedly stressed the importance of legal aid to guarantee effective access to a lawyer, especially during the initial phase following arrest and detention. ${ }^{208}$ Further, the conditions of detention and the nature of treatment of detainees should not be contingent on payment. ${ }^{209} \mathrm{In}$ addition, strict compliance with the exclusionary rule set out in Article 15 of the Convention is critical as economically marginalised persons are typically at a higher risk of being forced to confess. ${ }^{210}$

The SPT, in setting out its concept of prevention, specified 'that attention also be paid to the whole range of other factors relevant to the experience and treatment of persons deprived of their liberty and which by their very nature will be context specific'. ${ }^{211}$ Its approach to preventive visits is that they 'should be carefully prepared in advance taking into account all relevant factors $\ldots$ as well as the practical contexts in which they operate'. ${ }^{212}$ It entails that monitoring bodies develop a detailed understanding of how poverty affects the situation of individuals in detention settings, and include relevant factors in their visiting methodology and reporting. ${ }^{213}$

Impunity for torture is a systemic problem worldwide, which is particularly pronounced for persons living in poverty. ${ }^{214}$ Combating such impunity requires criminalisation of torture in conformity with Article 4 of the Convention, with the abuse of heightened vulnerability constituting an aggravating factor. ${ }^{215}$ Complaints procedures and investigations must be independent, with personnel involved therein trained in recognising and addressing issues and

205 UN Doc CAT/C/54/2 (n 67) para 78.

207 Carver and Handley (n 3) 2-3.

208 UN Committee against Torture, 'Concluding Observations on the Second Periodic Report of Namibia’ (1 February 2017) UN Doc CAT/C/NAM/CO/2, para 11(c).

209 See rule 2(2) of the Nelson Mandela rules, GA Res. 70/175, Annex (17 December 2015) and rule 1 of GA Res. 65/229, United Nations Rules for the Treatment of Women Prisoners and NonCustodial Measures for Women Offenders (the Bangkok Rules) (21 December 2010).

210 UN Doc A/71/298 (n 175). $\quad 211$ UN Doc CAT/OP/12/6 (n 191) para 3.

212 ibid para 5(e). $\quad 214$ ibid para 5(i). $\quad 214$ UN Doc A/73/207 (n 19) paras 24, 33, 65.

215 See eg UN Committee against Torture, 'Concluding Observations on the Sixth Periodic Report of Bulgaria’ (15 December 2017) UN Doc CAT/C/BGR/CO/6, para 30(a). 
risks arising from vulnerabilities, and accessible to persons living in poverty. This entails that complainants enjoy adequate protection, with threats, harassment or other such misconduct subject to adequate punishments, particularly where they exploit vulnerabilities. Officials should be required to report any risk of torture they are aware of and engage with individuals and members of the community concerned to instil confidence in the measures taken. ${ }^{216}$ The collection of data showing how many persons from which background, including socio-economic status, have brought complaints of torture, with which outcome, is an important systemic measure enabling States to assess and act on the effectiveness of complaints procedures and investigations. ${ }^{217}$

The close connection between corruption and torture is increasingly acknowledged. Corruption not only exposes individuals to the risk of coercive practices but also frustrates the effective exercise of rights where it undermines the functioning of criminal justice systems. The Special Rapporteur on Torture usefully called on States to break the link between corruption and torture, including by taking 'proactive efforts to ensure adequate funding, training and equipping of public services and institutions'. ${ }^{218}$ States must therefore make combating corruption an integral part of torture prevention measures and include corruption in the mandate of monitoring mechanisms and the scope of investigations into torture where appropriate. ${ }^{219}$

The provision of training on the prohibition ${ }^{220}$ has to be effective and include a focus on vulnerability and corruption. ${ }^{221}$ It has to be aimed at inculcating an understanding of how persons living in poverty are at an enhanced risk of torture and experience difficulties in exercising their rights, and what measures officials and other persons need to take to discharge the State's heightened obligation. Similarly, the systematic review of rules, methods and practices in the detention context $\mathrm{t}^{22}$ must include a focus on how to address vulnerabilities, including poverty, with a view to minimising the risk of torture. The obligation to take effective preventive measures entails that States take broader reforms in case of systemic failings. Empirical research has demonstrated that successful police reforms create a structure and instil an ethos that enhances the likelihood of effectively implementing the State's obligations in the day-to-day work of the police, or other law enforcement agencies. ${ }^{223}$

216 See eg rules 36, 39, 44, 46 of the European Code of Police Ethics, Recommendation Rec (2001) 10 adopted by the Committee of Ministers of the Council of Europe on 19 September 2001 and explanatory memorandum.

217 See eg UN Doc CAT/C/BGR/CO/6 (n 215) para 28(f).

218 UN Doc A/HRC/40/59 (n 18) para 70.

219 ibid paras 71-72; UN Doc CAT/C/54/2 (n 67) paras 82, 98.

220 Convention against Torture, art 10.

221 On the limits of training that is not part of wider reforms, Andersen (n 164) 181-2.

222 Convention against Torture, art 11.

223 Carver and Handley (n 3) 80. 


\section{Reparation}

The right to an effective remedy and reparation combines justice for victims with a preventive function. ${ }^{224}$ The Special Rapporteur on Extreme Poverty and Human Rights has highlighted the crucial role of access to justice in 'tackling the root causes of poverty, exclusion and vulnerability'. ${ }^{225} \mathrm{He}$ identified a series of obstacles faced by persons living in poverty, including in respect of physical access, fees and costs, corruption, and legal representation. ${ }^{226}$ Effectively addressing these obstacles is a prerequisite for an effective remedy for torture. ${ }^{227}$ Adopting a victim-centred approach is particularly salient in this context. If reparation is to serve its broader function of a public recognition of the equal worth of members of a community, restoration of civic trust and solidarity with victims, being recognised as a right-holder and subject become crucial components of the reparative process. ${ }^{228}$

Each of the recognised forms of reparation provides considerable scope to take into consideration specific vulnerabilities and the impact of torture. Compensation attentive to the special circumstances of persons living in poverty has utilised the national minimum wage for casual workers to calculate pecuniary damages and award moral, non-pecuniary damages for the suffering resulting from the abuse of a vulnerable position. ${ }^{229}$ The award of exemplary damages is particularly appropriate in such cases to signal that torture comes at a price, thereby reversing the very logic that persons living in poverty can be ill-treated with impunity. ${ }^{230}$ Rehabilitation is to be tailored to the situation of the individual victim, including lack of means and other poverty-related factors impeding access to relevant services, and may have a collective dimension where members of a group who have been targeted suffer trauma and other negative consequences. The element of satisfaction encompasses apologies, accountability and symbolic measures, all of which can have a discrete reparative function for victims of torture living in poverty. Ensuring criminal accountability is as important as it is difficult to break the climate of impunity by adequately investigating torture and bringing its perpetrators to justice. Where torture is systemic, investigations must equally seek to establish causes and patterns of ill-treatment and institutional responsibility.

${ }^{224}$ CAT, General Comment No 3 (n 59) paras 5, 18.

${ }^{225}$ UN Human Rights Council, 'Report of the Special Rapporteur on Extreme Poverty and Human Rights' (9 August 2012) UN Doc A/67/278, para 5.

227 General Comment No 3 (n 59) paras 32, 39.

${ }_{228} \mathrm{P}$ de Greiff, 'Justice and Reparations' in P de Greiff, The Handbook of Reparations (Oxford University Press 2006) 451.

229 See overview in JM Pasqualucci, The Practice and Procedure of the Inter-American Court of Human Rights (2nd edn, Cambridge University Press 2013) 229-40.

${ }^{230}$ See on exemplary damages, P Pinto de Albuquerque and A van Aaken, 'Punitive Damages in Strasbourg' in A van Aaken and I Motoc (eds), The European Convention on Human Rights and General International Law (Oxford University Press 2018) 230. 
The CAT emphasised that 'guarantees of non-repetition offer important potential for the transformation of social relations that may be the underlying causes of violence'. ${ }^{231}$ Legislative reforms, such as decriminalisation, measures to reduce pretrial detention, and the provision of legal aid, institutional reforms of dysfunctional criminal justice systems and training on the nexus between poverty and torture will often be essential. Beyond this, a careful analysis is required to tackle underlying causes of torture, including material conditions, socio-economic logics in highly unequal societies, and public discourses. Sandra Fredman's transformative approach to substantive equality as consisting of redressing disadvantage; redressing stigma, stereotyping, and humiliation; the participative dimension: social inclusion and political voice; and accommodating difference and structural change provides a useful reference point in devising reparation measures aimed at overcoming discrimination. ${ }^{232}$ Transformative reparation measures aimed at tackling underlying structures are particularly important in the context of reparation programmes forming part of transitional justice processes. As McGregor highlighted, such programmes have constituted missed opportunities to address systemic issues, which includes discrimination and poverty. ${ }^{233}$

\section{The Guiding Principles and torture prevention strategies}

Torture of persons living in poverty is conditioned by socio-economic structures and practices characterised by and producing discrimination and exclusion. An effective prevention strategy must seek to redress the power disparity resulting from these structures. The Guiding Principles offer agreed upon principles and tailored standards that can be used both to identify specific measures to be taken to prevent torture of persons living in poverty ${ }^{234}$ and to implement complementary policies and practices. The heightened obligation requires States to take vulnerability, here as a result of poverty, into consideration when designing and implementing effective human rights policies and preventive measures. Procedurally, the Guiding Principles require States to respect persons living in poverty as right-holders and to ensure that they are able to participate in decision-making processes. The importance of such participation has been recognised in the humanrights based approach to development, in response to concerns over treating marginalised persons as passive beneficiaries rather than as rights-holders. ${ }^{235}$

231 General Comment No 3 (n 59) para 18.

232 S Fredman, 'Substantive Equality Revisited' (2016) 14 IJCL 712.

233 L McGregor, 'Transitional Justice and the Prevention of Torture' (2013) 7 IJTJ 29, 44-51.

234 Guiding Principles (n 122) para 64.

235 M Broberg and H-O Sano, 'Strengths and Weaknesses in a Human Rights-Based Approach to International Development - An Analysis of a Rights-Based Approach to Development Assistance Based on Practical Experiences' (2018) 22 IJHR 664. 
It is equally valid in respect of the prohibition, to ensure that persons living in poverty, their representatives, and organisations genuinely advocating on their behalf have an active role in policymaking processes and in the design and implementation of relevant measures, such as being consulted on police reforms. Substantively, the Guiding Principles require States to respect dignity and equality and to have a particular focus on children. Where persons are known to be at particular risk of any form of ill-treatment because of their disadvantaged status in society, States must take measures that redress such disadvantage. Several instruments aimed at eliminating discrimination and Fredman's transformative approach to equality provide useful guidance on how to tackle systemic disadvantage.

This contextual interpretation links poverty eradication with torture prevention. States have already assumed a series of legal obligations which, if adequately implemented, are expected to reduce poverty, including the right to equality, economic, social and cultural rights, the right to democratic participation, and the right to development. ${ }^{236}$ These rights are integral components of broader prevention strategies to break the connection between poverty and torture. Bodies tasked with monitoring the implementation of these rights can play an important role in highlighting this relationship where such evidence is provided to them, or is otherwise apparent, which includes the detrimental impact of torture on economic, social and cultural rights.

Requiring States to develop and implement coherent and integrated policies on combating torture, corruption, and poverty eradication are important measures in a wider, systemic approach to torture prevention. ${ }^{237}$ As higher levels of income and equality within and across society are recognised as indicators of greater respect for human rights, it is critical that States and international organisations effectively address the structures and interests that produce and sustain poverty and inequality, and tolerate if not encourage recourse to torture to preserve and serve powerful interests.

\section{Developing a Contextual Approach and Engaging Persons Living in Poverty}

A contextual approach to the prohibition represents a challenge and opportunity for actors working on torture prevention. For States and national human rights institutions, developing a situational understanding of poverty and torture requires collecting relevant data. It also entails opening channels of communication and fora to engage with persons living in poverty and those who represent them or advocate on their behalf, to inform policymaking and reforms addressing the causes, practice and impact of torture. At the

236 UN Doc E/C.12/2001/10 (n 123).

237 UN Doc A/HRC/40/59 (n 18) para 71, on corruption and torture; UN Doc A/HRC/44/40 (n 113) on poverty eradication. 
international level, the SPT has already developed a practice of focusing on and seeking to address poverty and other vulnerabilities. The Special Rapporteur on Torture has recently developed a closer focus on contextual factors, such as corruption, and their relation to torture. There is considerable scope for the CAT and other bodies to pay closer attention to the torture of persons living in poverty. Requesting information collected in a human rights compliant manner about the treatment of persons living on the street, the criminalisation of petty offences, the scale and demography of pretrial detention and prison populations, disaggregated data on torture-related complaints and their outcome, the availability of legal aid, corruption, modalities for monitoring of vulnerable groups in detention, and their access to justice ought to be standard issues raised in monitoring States parties' compliance. Building on its General Comment No 2 and its 2018 one-day session on vulnerable groups and torture, developing a thematic general comment would provide the Committee with the opportunity to set out the obligation of States parties in respect of vulnerable persons, particularly with respect to poverty.

For NGOs working on torture, a useful starting point would be an audit to identify the extent to which, and how an organisation has interacted with persons living in poverty, and how this interaction is reflected in their work and publications. Such audit should heed the findings of the research by Jensen and others in terms of how organisational location, priorities, modus operandi and biases, including class dynamics, impact on their work. ${ }^{238}$ Donor policies and funding priorities are also material factors meriting further scrutiny in this context. Legal interventions, documentation, monitoring, and advocacy ought to focus on, and integrate the role of poverty, and other characteristics where applicable. This entails, for example, drawing attention to the discriminatory dimension of a case, and requesting forms of reparation that address the same.

An overly formalistic and legalistic approach to the torture of persons living in poverty bears the risk of replicating asymmetric power relationships and of bringing about limited change. The Centre for the Study of Violence and Reconciliation and Dignity have, in the South African context, developed 'a community work model for addressing torture' influenced by social action theory and the ecological model. ${ }^{239}$ At its core, it views systems as interconnected and aims at mobilising 'community members to become "active citizens", ${ }^{240}$ Its aim is to empower and connect people to effect change in their communities, including by identifying and reducing risk factors, providing support to victims, and translating experiences and interventions into advocacy efforts. ${ }^{241}$ Such approaches are exemplary, reflecting a broader call to listen, to have a serious dialogue and to be attentive to the lived experiences of persons who have been excluded,

238 Jensen et al. (n 4). $\quad 239$ Bantjes et al. (n 4) 53. $\quad{ }^{240}$ ibid. $\quad 241$ ibid. 
silenced and frequently exposed to human rights violations. ${ }^{242}$ They have enormous transformative potential but require sustained and challenging engagement to tackle what are typically deep-seated structural problems resulting in violent encounters.

\section{CONCLUSION}

Persons living in poverty, although bearing the brunt of routine, institutionalised torture practices, remain at the margins of prevention efforts. They still frequently find themselves subsumed under the rubric of another group defined with reference to other characteristics such as age or gender. There is no consistent practice of fully taking into consideration their situation and experiences, and to translate them into tailored, heightened obligations of States to prevent torture and provide justice. Human rights bodies and defenders' growing awareness of the nexus between poverty and torture is an overdue development that calls for a concerted effort to have it reflected in the interpretation of the prohibition, and to design and implement targeted preventive measures. Legal interventions that contextualise and broaden the conventional torture prevention framework constitute an important part of a wider strategy to combat torture. At a time of growing inequality, populist vilification of marginalised persons and anxiety, transforming what are often deeply entrenched patterns of discrimination, exclusion and violent, abusive power relationships constitutes a major challenge.

In addition to prioritising reforms in the administration of justice, particularly of legislation and institutions such as law enforcement agencies, the larger political struggle requires mobilisation and participation to counter disempowerment and dehumanisation. Notions of dignity as a levelling up of status, ${ }^{243}$ or of treating individuals as equals on account of their social identity and right to be protected from inferiorising treatment and cruelty ${ }^{244}$ are pertinent here. Yet, realising them will require profound material changes in relation to how contemporary societies produce stratification maintained by degrees of violence. Redressing national and international inequality through tailored legal approaches combined with a fundamental political, economic and societal transformation is therefore indispensable when seeking to reduce if not altogether eliminate the epidemic of torture that all too often forms an integral threat, if not part of the lives of persons living in poverty.

242 Heathcote (n 189).

243 J Waldron, Dignity, Rank, and Rights (Oxford University Press 2012).

244 A Sangiovanni, Humanity without Dignity: Moral Equality, Respect, and Human Rights (Harvard UP 2017). 